\section{Studia \\ z Filologii Polskiej i Słowiańskiej}

DOI: $10.11649 /$ sfps.1966
Studia z Filologii Polskiej i Słowiańskiej, 55

Warszawa 2020

Article No. 1966

Citation:

Шевченко, Л. І., \& Сизонов, Д. Ю. (2020). Стан і перспективи дискурсивно-стилістичної лексикографії: огляд проблеми. Studia z Filologii Polskiej i Słowiańskiej, 55, Article 1966. https:// doi.org/10.11649/sfps.1966

Shevchenko, L. I., \& Syzonov, D. I. (2020). Stan i perspektyvy dyskursyvno-stylistychnoï leksykohrafiii: ohliad problemy. Studia z Filologii Polskiej i Słowiańskiej, 55, Article 1966. https://doi.org/10.11649/sfps.1966

\author{
Лариса Іванівна Шевченко \\ (Київський національний університет \\ імені Тараса Шевченка) \\ Дмитро Юрійович Сизонов \\ (Київський національний університет \\ імені Тараса Шевченка)
}

\title{
Стан і перспективи дискурсивно-стилістичної лексикографії: огляд проблеми
}

\section{1. Сучасна лексикографія: еволюція наукових підходів}

У сучасній науці актуалізовано аналіз словників у контексті дискурсивно-стилістичного підходу (Клушина, 2019, сс. 300-305), що є домінантним у лінгвістиці модерного часу. В інформаційну добу лексикографія стала інтердисциплінарною, синкретичною та інноваційною сферою наукового знання, що апробовує досвід кількох наук, насамперед мовознавства, семіотики та інформатики / кібернетики. Використання комп'ютерних

This is an Open Access article distributed under the terms of the Creative Commons Attribution 3.0 PL License (creativecommons.org/licenses/by/3.0/pl/), which permits redistribution, commercial and non-commercial, provided that the article is properly cited. (C) The Author(s) 2020.

Publisher: Institute of Slavic Studies, Polish Academy of Sciences

[Wydawca: Instytut Slawistyki Polskiej Akademii Nauk] 
технологій у лінгвістиці визначило інноваційні тенденції: інтенсивно розвиваються корпусна та кібернетична лексикографія (Карпова, 2000; Широков, 2004), метою яких є лексикографічне опрацювання матеріалу за допомогою електронних систем.

Початок нового тисячоліття $є$ продуктивним на неолінгвістичні ідеї, що визначають формування юрис- та медіалінгвістики, лінгвістичної експертології, аксіологічної та сугестивної лінгвістики, бізнесового та політичного мовознавства. Нові дослідницькі парадигми впливають на зміну наукових векторів: від традиційного структурно-системного підходу (т. зв. «теоретико-описового»; Апресян, 1995) - до функціонально-прагматичного, «прикладного» (порівняємо проблематику авторитетних світових журналів: «International Journal of Lexicography» (Великобританія), «Cahiers de Lexicologie» (Франція), «The Mental Lexicon» (Данія), «Вопросы лексикографии» (Росія), що актуалізують нові ракурси дискурсивно-функціональної лексикографіі).

Якщо раніше (початок XX ст.) основним завданням світової лексикографії було укладання галузевих словників, то вже із середини XX ст. пріоритетності набувають т. зв. енциклопедичні словники та словники дискурсивного типу. Зокрема, українські мовознавці представили на XV Міжнародному з'їзді славістів медіа- та юрислінгвістичні словники, принципи укладання та лінгвістичний зміст яких були схвально сприйняті й обговорені колегами-славістами. Було окреслено, отже, коло найбільш актуальних проблем дискурсивно-стилістичної лексикографії.

Становлення неолінгвістичних концепцій тільки підсилило цю тенденцію, адже мова стрімко розвивається, залучається новий інструментарій для її вивчення. Слушно з цього приводу зауважує польський дослідник С. Гайда:

Якщо змінюється світ і з ним мова, то можна очікувати перевтілення людського мисленн я про неї, а також у створюваних нею дискурсах. [...] Якщо сьогодні світ стає неупорядкованим, то ведеться пошук ідей і теорій, які укладали 6 новий тип пізнавального досвіду (Гайда, 2015, с. 16).

Використання словників з кінця XX ст. передбачає орієнтацію на комунікативні потреби соціуму, а отже, моделювання функцій словник користувач. Дж. Вільямс наголошує, що для ефективного користування лексикографічним джерелом потрібно вміти обирати відповідний тип словника для адекватного задоволення потреб користувачів, знати основні 
складники на макро- й мікроструктурному рівнях, легко знаходити потрібну реєстрову одиницю, адекватно сприймати інформацію про мовну одиницю в словнику (Williams, 2016, с. 79).

Саме на прагматиці й будуються сучасні теорії створення неословників. Інструкції до моделювання словників, їхньої структури, збору матеріалу та власне укладання вже на початку XXI ст. були науково інтерпретовані, систематизовані й видані сучасними українськими лінгвістами (Дубічинський, 2015; Тараненко, 2000; Шевченко та ін., 2014). Українська лексикографія фактично орієнтується на створення словників, що мають бути актуалізованими в умовах глобалізаційних інформаційних процесів. Наукові паралелі можна провести з подібними тенденціями у світовій лексикографії, що є очевидним та логічним (бачимо абсолютно інноваційну дослідницьку рефлексію на проблему в тріаді: personal computer - dictionary - user).

\section{2. Традиційна лексикографія vs комп’ютерна лексикографія}

2.1. У західноєвропейській лексикографічній практиці все активніше користувачі надають перевагу інноваційним словникам на основі комп’ютерних технологій. Підтвердження цьому - відхід від паперових версій лексикографічних джерел та породження сучасних словників у мережі Інтернет та / або на основі мови Інтернет-комунікаціі:

Із розвитком комп'ютерних технологій до традиційного тричленного ланцюжка створення словника додався четвертий складник - корпус. Корпус на сьогодні розуміють як базу текстів, розміщених для надання його користувачам інформації про формальні, семантичні й функціональні властивості слова, базу, збалансовану й показову для реального стану системи мови в певний період їі існування, як взірець «мови в дії» (Карпіловська, 2017, с. 94).

Очевидним виявляється й факт тотальної комп'ютеризації словникових систем не тільки лінгвістами, а й фахівцями в галузях кібернетики та інформаційних комунікацій. Шлях від паперової до комп’ютерної картотеки - еволюційний, адже лексикограф спрощує роботу собі, а також за допомогою технічних маркувань - користувачам. Пригадаймо в цьому 
контексті лексикографічні прориви на основі комп'ютерних технологій в Польщі та Україні:

(a) комп’ютеризований аналог (фактично один із перших цифрових словників у Польщі) Słownika języka polskiego - Komputerowy słownik języka polskiego PWN (Linde-Usiekniewicz, 1996);

(б) Wielki słownik języka polskiego - один із найбільших електронних проєктів Польської академії наук за ред. П. Жмігродського, який репрезентує еволюційну динаміку польської мови (Żmigrodzki, 2007);

(в) оновлений за вимогами часу Словник української мови (у 20-ти тт.), що видається Українським мовно-інформаційним фондом з електронною репрезентацією на сайті Словники України on-line ${ }^{1}$.

2.2. Із метою окреслення перспективи визначеної проблеми було проведене анкетування серед студентів Київського національного університету імені Тараса Шевченка (спеціалізація «Медіалінгвістика»), які вивчають курс «Медійна лексикографія» ${ }^{2}$ Студенти названої спеціалізації беруть активну участь у новому для українського наукового простору лексикографічному проєкті «Нові слова та фразеологізми в українських мас-медіа», що репрезентує динамічні процеси в українській масовій комунікації (див. п. 4 цієї статті).

Серед опитаних за допомогою електронної анкети $84 \%$ студентів віддали перевагу комп'ютерним типам словників, серед них 44 \% зовсім відмовляються користуватися паперовими версіями словників, якщо не знаходять лексичного значення в електронному форматі. Більше $60 \%$ студентів користуються тільки електронними словниками (комп'ютерні версії та додатки на мобільних телефонах), 34 \% 3 числа респондентів уважають, що треба створювати цифрові паралелі паперовим словникам, решта $є$ прибічниками створення принципово нових словників у комп'ютерному форматі. Усі опитані бачать майбутнє за електронними типами словників.

1 http://lcorp.ulif.org.ua/dictua/

2 Дослідження проводилося в рамках дисципліни та в межах робочої програми курсу «Медійна лексикографія» (автори - Л. Шевченко, Д. Сизонов) за допомогою електронного анкетування на платформі Google. Участь в опитуванні взяли 25 студентів 4-го та 27 студентів 3-го курсів, що склало $100 \%$ опитаних. За допомогою методу підрахунку виявлено, що понад дві третіх студентів користуються комп’ютерними словниками на противагу друкованим. 
Перспективи комп'ютерної лексикографії очима молоді (студенти спеціалізації "Медіалінгвістика")

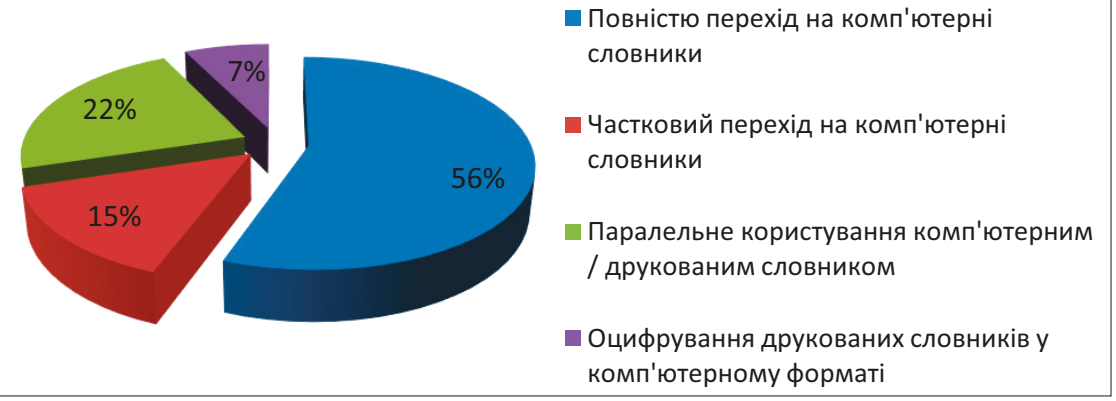

Діаграма 1. Результати електронного опитування студентів

Опрацьований матеріал має дослідницькі паралелі з визначеними перспективами в українській та польській лексикографії (Bańko, 2003; Дубічинський, 2004). Усі прогнози лексикографів, відомі ще з ХX ст., справдилися за дуже короткий термін: як показують результати досліджень новішого часу, сьогодні вже немає проблеми в обгрунтуванні необхідності створення компютерних лексикографічних систем. Завдання сучасних лексикографів зробити такі інноваційні словники більш зручними для користувача.

2.3. Нові думки щодо лексикографії в контексті формування медіалінгвістичного знання висловлювали лінгвісти ще у XX ст. Пригадаємо, зокрема, стилістичну школу функціоналізму з ідеями швейцарського лінгвіста Ш. Баллі, який зосередив дослідницьку увагу на раціональній організації мовних одиниць у мовленнєвому потоці. Дослідники-функціоналісти звернулися до аналізу мовної дійсності в її об’єктивації щодо людських потреб, соціальних чинників, екстралінгвальних мотивацій. Наголосімо й на актуальній теорії лінгвопрагматизму, предметність якої пов'язується з використанням мовних одиниць у різних типах і сферах комунікації - мова та політика, мова та право, мова та культура, мова та масмедіа.

У США, наприклад, актуалізується т. зв. практична (прагматична) лексикографія (practical lexicography) (Svensén, 1993, с. 14), а згодом медійна лексикографія (media lexicography) (Kirkness, 2004, с. 56). У світовій практиці еталоном високого лексикографічного стандарту стали французькі (Le Robert, Larousse, Tresor), німецькі (Duden), британські (Oxford, Chambers, Collins, Hamlyn, Longman, Macmillan), польські (PWN) видавництва. 
Необхідно наголосити й на тому, що дискурсивно-стилістична лексикографія пов’язана з розвитком ідей сучасної теорії прагмалінгвістичного медіамоніторингу (Добросклонская, 2005, с. 252) - нового напряму й відповідного дослідницького методу в медіалінгвістиці. Прагмалінгвістичний медіамоніторинг передбачає спостереження за мовою ЗМІ з метою виявлення слів, словосполучень і речень, актуальних для сучасного соціуму: в майбутньому вони можуть стати базисом для укладання різних словників медіасфери: не «словник для словника», а «словник для користувача», чим концептуально відрізняється словник XXI ст. від словників минулого.

Отже, медійна лексикографія - це комплексна номінація, що об'єднує різні типи медійних словників (описові, дискурсивні, термінологічні, перекладні та ін.), які систематизують фахову термінологію та професійну лексику працівників медіа; лексикографічний напрям, завданням якого є представлення й аналіз медійної комунікації - її стилістичного ресурсу, комунікативних тактик та стратегій, що можуть стати об'єктом для дослідження та систематизації.

\section{3. Ретроспективний аналіз медійної лексикографії: Польща / Україна}

У Польщі медійну лексикографію визначають як перспективний напрям ще наприкінці 70-х років XX ст., що пов'язано з провідною роллю медіа у становленні мовної свідомості індивідуального / масового реципієнта в сучасному соціумі та як результат - необхідності укладання словників, що репрезентують тенденції розвитку мови.

У Польщі з кінця 60-х рр. започатковуються дослідження, що авторитетно репрезентують медійну сферу (Kafel, 1969; Maślanka, 1976), а також генерують ідеї для наступних поколінь лексикографів (див. Pisarek, 2006 та ін.). Назване останнє видання без перебільшення стало хрестоматійним для слов'янського мовознавчого світу в контексті укладання неословників. Обгрунтування цього поняття знаходимо у бюлетені за результатами з'їзду Європейської асоціації лексикографів (Williams, 2016). Під медійним неословником розуміємо словник медіа з оновленими структурою, способами представлення (напр., за допомогою інтернет-платформ) та прагматичними завданнями. До слова, польський славіст С. Гайда 
сформулював позицію щодо укладання універсальних енциклопедичних (двомовних) словників мас-медіа, зокрема й польсько-українських, українсько-польських у межах Стилістичної комісії на XV Міжнародному з'їзді славістів (м. Мінськ, Республіка Білорусь, 20-27 серпня 2013 р.).

Відбиваючи світові тенденції особливої уваги до мови медіа, в Україні також виникає потреба в укладанні принципово нових комплексних дискурсивно-стилістичних лексикографічних праць, до числа яких і належить перший медіалінгвістичний словник (Шевченко та ін., 2014). Аспектне представлення лексикографічного опрацювання конкретного мовного матеріалу в медіа передувало появі такого словника (Дергач, 2009; Ільченко, 2012; Ільченко \& Приступа, 2016; Сизонов, 2012; Чемеркін, 2009 та ін.).

Створення таких лексикографічних праць мотивовано стрімким зростанням інформатизації в сучасному соціумі, переформатуванням наявних джерел і способів передачі інформації, а також появою нових медійних платформ і, відповідно, жанрів, їхньої композиційної та архітектонічної специфіки - все це вимагало фахового структурування термінопонять.

Лексикографічне видання Медіалінгвістика: словник термінів і понять $\epsilon$ інноваційним в українській лексикографії, орієнтованим не тільки на ідеї вітчизняних лексикографів, а й зарубіжних. Словник відповідає новим вимогам користувачів до видань нового типу - обгрунтовано зручність у користуванні й максимально можливий швидкий пошук потрібної інформації, адже сучасний користувач словників «швидше віддасть перевагу єдиному словнику, що містить як всебічні знання про мову, так і спектр енциклопедичних знань» (Большаков \& Гельбух, 2011, с. 124). У перспективі роботи над словником - електронна адаптація видання до потреб сучасного користувача та розширення медіалінгвістичних термінів з їх актуалізованими дефініціями.

\section{4. Медіасловник майбутнього та накреслення дослідницьких перспектив}

4.1. Укладання інноваційних словників диктується глобальними потребами сучасного комуніканта бути першим в отриманні інформації. Відповідно нові словники «сприятимуть кодифікації вже наявних принципів укладання словникової продукції та розробленню новітніх підходів у практичній лексикографії (Тараненко, 2000). Зокрема, роз- 
роблення комп'ютерних лексикографічних систем грунтовно проаналізовано в монографічній праці акад. В. Широкова: схарактеризована наукова діяльність Українського мовно-інформаційного фонду НАН України як дослідницької інституції, сформульовано принципи функціонування сучасних мовно-інформаційних систем та становлення комплексу лінгвістичних технологій у процесі створення т. зв. СЛОВНИКА МАЙБУТНЬОГО. Лексикографи фонду фактично запропонували нову концепцію електронного словника та комп'ютерну технологію сучасної лексикографічної діяльності. Відповідно автор трактує лексикографію, дотримуючись «класичних поглядів, що грунтуються на системному баченні теорії й методології лексикографування, власне процесу лексикографування та сукупності лексикографічних праць» (Широков, 2004, c. 10) і водночас пропонує технічно опрацьований системний підхід до специфіки роботи зі створення нових словників. Концептуалізованою та перспективною, на наше переконання, $\epsilon$ спільна робота в межах підготовки словника Leksykon aktywnej frazeologii polskiej i ukrainskiej (2018; Tymoshuk та ін., 2018), що включає опрацювання фразеологічного фонду на основі сучасного розмовного стилю, художньої літератури, мови медіа Польщі та України.

Окреслюючи перспективу медійної лексикографії, не можемо не зупинитися на новому для української медіалінгвістики лексикографічному проєкті «Нові слова і фразеологізми в українських мас-медіа» (2017, 2018, 2019 рр.), що дає змогу діагностувати реальний стан і статус сучасної української мови в масовій комунікації. Названий проєкт за участі молодих учених - студентів спеціалізації «Медіалінгвістика» Київського національного університету імені Тараса Шевченка - має на меті проаналізувати процес оновлення лексико-фразеологічного фонду України. Спроби аналогічної роботи вже були: проєкти під керівництвом проф. Г. Солганика, Інституту лінгвістичних досліджень РАН за матеріалами преси 60-80-х та 80-90-х рр. ХХ ст., численні проєкти Оксфордської лексикографічної традиції, Варшавського університету «Młodzieżowe słowo roku» та ін. Наголосимо водночас на особливостях роботи зі словниками в інформаційну добу, про що йшлося вище, а також дискусійних наукових проблемах у сучасній лексикографії, що відбито і в науковій літературі (Adamska-Sałaciak, 2019; Иванцова, 2013; Нелюба \& Нелюба, 2007; Пурицкая \& Панков, 2018; Степаненко, 2017; Стишов, 2005; Шестакова, 2015 та ін.). 
4.2. Перспективним $є$, на нашу думку, лексикографічний проєкт, реалізований як щорічна серія вербальних фіксацій динаміки сучасної суспільної комунікації (Шевченко \& Сизонов, 2017-2019). Аналізуючи принципи відбору нових слів і фразеологізмів у медіа та формуючи відповідну е-картотеку, укладачі коректно і максимально об’єктивно представили мовний матеріал в медійних контекстах.

Три видання словника налічують понад 1000 мовних інновацій, що спираються на критерії:

Табл. 1. Критерії роботи над словником

\begin{tabular}{|c|c|c|}
\hline $\begin{array}{l}\text { КРИТЕРІЇ } \\
\text { ВІДБОРУ }\end{array}$ & КРИТЕРІЇ ПРЕЗЕНТАЦІЇ НОВИЗНИ & 잉 \\
\hline $\begin{array}{l}\text { нове, раніше } \\
\text { не фіксоване } \\
\text { у словни- } \\
\text { ках, слово / } \\
\text { фразеологізм; } \\
\text { нове значення } \\
\text { слова, тран- } \\
\text { сформованого } \\
\text { фразеологізму }\end{array}$ & $\begin{array}{l}\text { мовна одиниця представлена у щонайменше трьох } \\
\text { медійних контекстах із вказівкою на джерело комуні- } \\
\text { кації; визначається семантика слова / фразеологізму, їх } \\
\text { основні граматичні параметри; наводяться лексичні та } \\
\text { граматичні варіанти мовної одиниці й відповідні кон- } \\
\text { тексти; фіксується тематика та жанр суспільної комуні- } \\
\text { кації; за необхідності подаються парадигмальні харак- } \\
\text { теристики мовної одиниці - синонімічні, антонімічні та } \\
\text { ін.; у випадках запозичення - вказується мова-донор }\end{array}$ & 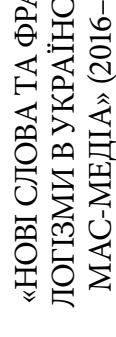 \\
\hline
\end{tabular}

Проєкт розрахований на десять років (2016-2026 рр.) і супроводжується щорічним науковим звітом у вигляді лексикографічної праці.

Для репрезентації активних неологічних процесів в українській мові, виявлених у 3MI, джерельну базу для досліджуваного матеріалу визначено за кількома критеріями:

(1) аналітично сформульованого в теоретичних працях медіалінгвістів опису активних процесів розвитку української мови, передусім у сфері масової комунікації;

(2) укладання е-картотеки, сформованої на основі лексикографічного представлення зібраного відповідно до фахового анкетування матеріалу, що включає різні носії інформації (друковані видання, радіо, телебачення, реклама, інтернет та ін.), синкретизм медійних жанрів;

(3) лінгвістичної обєктивації нових мовних інновацій в українській мові;

(4) подання та паспортизації нової фразеології, що виникає та функціонує у сфері масової комунікації. 
Укладачі зосереджують увагу на нових словах/фразеологізмах із мов-донорів, передусім англійської (Phillipson, 1992; Syzonov, 2018). Зауважено, що в процесах неологізації вплив на суспільну сферу комунікації в Україні має і польська мова як одна з потужних мов Європейського Союзу, близького політично й культурно сусіда нашої держави. Запозичення з польської мови (або за посередництвом польської мови) впливали і впливають на мовну свідомість сучасних українців (Дика, 2010; Крехно, 2012), що представлено матеріалами словника.

Слід підкреслити, що деякі лексико-фразеологічні новації $є$ послідовним відтворенням польськомовних аналогів (особливо в Інтернет-просторі) - і це також може бути об'єктом лексикографічного аналізу, зокрема janusz, keczup po frytkach, na Pazdana, rejczel та ін.

Див. у словнику (Шевченко \& Сизонов, 2017-2019):

«Стиль Паздана» (пол. «na Pazdana») - зачіска в стилі польського футболіста М. Паздана («під нуль», «під насадку»): «Стиль Паздана» в українській політиці: мода на лисих [Zik, із заголовку, 20.11.2018]; Яма і Кошовий: «стиль Паздана» по-українськи [Новий час, 10.10.2018]; Szachiści liderami olimpiady - Bartel zmieni fryzurę «na Pazdana» [Polskie Radio, із заголовку, 03.10.2018].

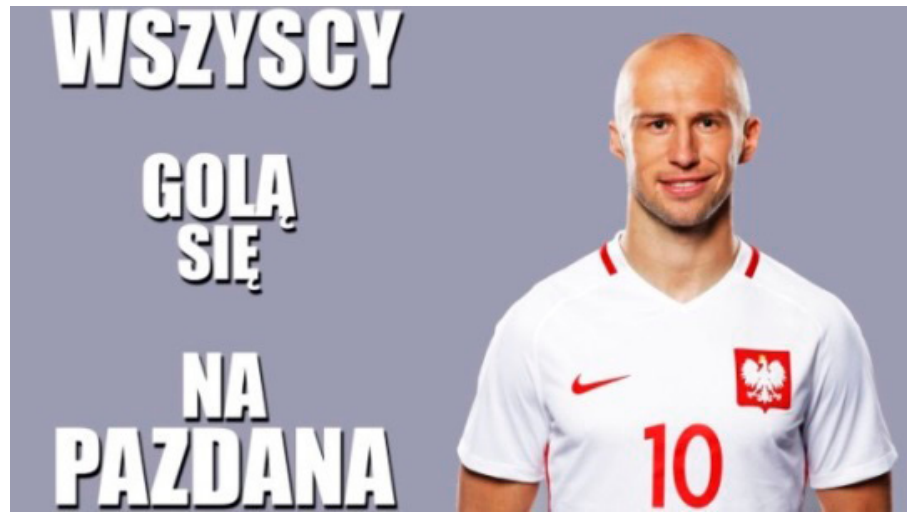

Джерело: Facebook

Януш; типовий Януш (пол. janusz, typowy janusz) - Інтернет-мем, що характеризує типового «героя»: Януші серед нас: або як живуть нинішні україниі-заробітчани у сусідній Польщі [Дзеркало тижня, 22.12.2017]; Kim jest typowy Janusz? Z tym pytaniem musi zmierzyć się wiele osób [Wirtualna Polska, із заголовку, 24.11.2018]. 


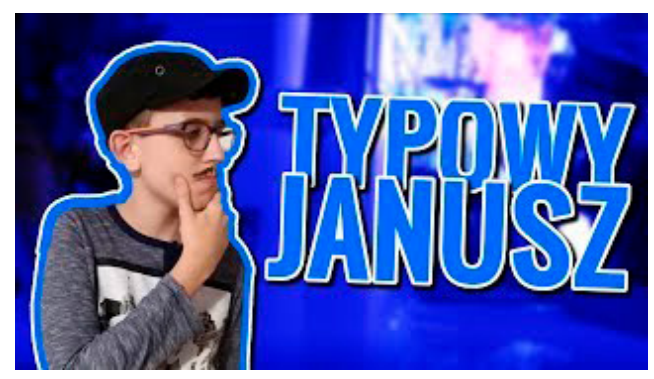

Джерело: Facebook

Оскільки робоча концепція запропонованого словника описана (Шевченко \& Сизонов, 2017), коректним буде зупинитися на ключових дискусійних моментах щодо впорядкування та перспектив роботи з медіаматеріалом. Упорядкування, здійснене за традиційним алфавітним принципом, може бути розширеним за допомогою зіставлень 3 аналогічними лексикографічними моделями в Україні та світі. Гіпотетичні висновки можуть стосуватися лінійних/нелінійних процесів розвитку мов у сучасну інформаційну епоху.

Для критерію новизни семантики важливим $є$ врахування частотності та типовості функціонування нової одиниці (нового значення) в медійному контексті. Перспективна лексикографія, особливо з використанням можливостей корпусної лінгвістики, дозволить збільшити кількість покликань на медійні тексти і контекст, а отже, об'єктивувати висновки щодо актуальних процесів трансформації мови/мов.

4.3. Для коректної репрезентації матеріалу важливими $є$ методи лексикографування, з яких у словнику актуалізовано:

(1) метод типологічних зіставлень у процесі фіксації та наукової паспортизації неологізмів, що був використаний як основний і послідовно застосований у лексикографічному представленні матеріалу;

(2) метод медіамоніторингу (прагматичного моніторингу), використаний для опрацювання максимально повного аналізу медіаджерел сучасної України. Так, до суцільної вибірки мовного матеріалу за допомогою зазначеного методу ввійшли медіатексти різних сфер (політичної, економічної, культурно-мистецької, освітньої та ін.), жанрів (інформаційно-аналітична, художньо-публіцистична група жанрів друкованої та електронної преси) й засобів зв'язку (радіо, телебачення, Інтернет, реклама та ін.). 
Для максимальної об’єктивації пошуку була розроблена авторська методика збору матеріалу, що корелюється зі світовими практиками укладання дискурсивно-стилістичних словників. Так, автори керувалися принципом частотного функціонування одиниці у 3MI: неологізм/неофразема має вживатися мінімум у 10-ти контекстах 10-ти медіаджерел (у словнику подано не менше трьох репрезентативних контекстів), що вказує на тенденцію інноваційної одиниці тиражуватися в медіа та відтворюватися в мовній свідомості масового реципієнта. До того ж перевага надавалася функціонуванню одного й того ж нового слова в різних типах медіакомунікації.

Усі покликання, зроблені укладачами, подаються в оригіналі, без унесення змін у медіатекст, редагування (незалежно від культурних страт, на які зорієнтовані певні медіаджерела). Стилістичне маркування словникових статей видається важливим у контексті динамічних змін у мові, коли, наприклад, слово виникає в політичній чи бізнесовій комунікації та швидко адаптується до мови масового реципієнта. Результати такого лексикографічного підходу дають змогу спостерігати за реальною динамікою семантичних змін у мові.

Робота над дискурсивно-стилістичним медійним словником дозволяє окреслити проблеми інноваційної лексикографії, що формується сьогодні і ще потребує різноаспектної аргументації в середовищі теоретиків і практиків модерного словникарства. Зокрема і в аспекті розвитку строгого системно-структурного підходу з урахуванням/зміною на дискурсивно-стилістичні можливості представлення словникового матеріалу. Безумовно, мають рацію дослідники, які розглядають сферу медіа як цілісний комунікативний об’єкт, де корелюються зв'язки між контентом, автором тексту, соціальним середовищем і реципієнтами. Медійна лексикографія відтак репрезентує, динамічно відтворює вербалізовану сутність і структуру масової комунікації, акцентуючи увагу на перспективах і тенденціях розвитку сучасних мов.

Очевидно, що лексикографічна діяльність подає системно організовані й дискурсивно опрацьовані мовні факти не як окремо взятий, самодостатній фрагмент мовної дійсності, а як результат змін в об’єктивному пізнаному й вербалізованому світі, де ефективне функціонування соціальних середовищ визначається мовою. Новий лексикографічний пошук у запропонованій постановці питання дозволяє усвідомити виклики, що стоять перед сучасною лінгвістикою в її адекватності потребам модерних суспільств в інформаційну еру, створюючи нові словники, що відповідатимуть вимогам часу. Суспільна комунікація в цьому аспекті 
$€$ найважливішим інструментом виміру цивілізованості та раціональної побудови у глобальному інформуванні, а отже, медійна лексикографія це серйозне й невідкладне питання сучасного мовознавства.

\section{Бібліографія}

Adamska-Sałaciak, A. (2019). Lexicography and theory: Clearing the ground. International Journal of Lexicography, 32(1), 1-19. https://doi.org/10.1093/ijl/ecy017

Bańko, M. (2003). Stan i perspektywy współczesnej polskiej leksykografii jednojęzycznej. In S. Gajda (Ed.), Jezzkoznawstwo w Polsce: Stan i perspektywy (pp. 127-142). Polska Akademia Nauk; Uniwersytet Opolski.

Kafel, M. (1969). Prasoznawstwo. Państwowe Wydawnictwo Naukowe.

Kirkness, A. (2004). Lexicography. In A. Davies \& C. Elder (Eds.), The handbook of applied linguistics (pp. 54-81). Blackwell. https://doi.org/10.1002/9780470757000.ch2

Linde-Usiekniewicz, J. (Red.). (1996). Komputerowy stownik języka polskiego. Wydawnictwo Naukowe PWN.

Maślanka, J. (1976). Encyklopedia wiedzy o prasie. Zakład Narodowy im Ossolińskich.

Phillipson, R. (1992). Linguistic imperialism. Oxford University Press.

Pisarek, W. (Ed.). (2006). Stownik terminologii medialnej. Towarzystwo Autorów i Wydawców Prac Naukowych "Universitas".

Svensén, B. (1993). Practical lexicography: Principles and methods of dictionary-making. Oxford University Press.

Syzonov, D. (2018). Media phraseology and the dynamics of the Ukrainian language: The psycholinguistic and stylistic paradoxes. Psycholinguistics, 24(2), 277-292. https:// doi.org/10.31470/2309-1797-2018-24-2-277-291

Tymoshuk, R., Sosnowski, W., Jaskot, M., \& Ganoshenko, Y. (2018). Leksykon aktywnej frazeologii polskiej i ukraińskiej. KJV Digital Sp. z o.o.

Williams, G. (2016). In praise of lexicography, and lexicographers. In T. Margalitadze \& G. Meladze (Eds.), Proceedings of the XVII EURALEX International Congress (pp. 77-88). Ivane Javakhishvili Tbilisi State University.

Żmigrodzki, P. (Ed.). (2007). Wielki słownik języka polskiego PAN. Instytut Języka Polskiego PAN. http://www.wsjp.pl

Апресян, Ю. (1995). Избранные труды: Vol. 2. Интегральное описание языка и системная лексикография. Языки русской культуры.

Большаков, И., \& Гельбух, А. (2011). Большой электронный словарь как политематический справочник и формирователь запросов к интернету. In A. Е. Кибрик et al. (Eds.), Диалог 2011 (рр. 124-134). Изд-во РГГУ. 
Гайда, С. (2015). Актуальные задачи стилистики. Актуальные проблемы стилистики, 2015(1), 11-22.

Дергач, Д. (2009). Словник онімів українських мас-медіа. “Київський університет”.

Дика, Л. (2010). До проблеми польських запозичень в українських говірках. In J. Rieger (Ed.), Studia nad polszczyzna kresowa (Vol. 12, pp. 251-258). Wydawnictwo Naukowe Semper.

Добросклонская, Т. (2005). Вопросы изучения медиатекстов: Опыт исследования современной английской медиаречи. УРСС.

Дубічинський, В. (2004). Украӥнська лексикографія: Історія, сучасність та комп’ютерні технологї. НТУ "ХПІ".

Дубічинський, В. (2015). Сучасна лексикографія ХХІ сm. ХТУ.

Иванцова, Е. (2013). Лексикографическое представление речи индивида: Тип словаря и его реализация в словарной практике. Вопросы лексикограбии, 2013(2(4)), 6-18.

Ільченко, О. (2012). Вербалізоване “обличчя” сучасного суспільства: Словник метафоричних словосполучень української преси (2000-2010). [n.p.].

Ільченко, О., \& Приступа, Т. (2016). Вербалізоване “обличчя" сучасного суспільства в діалозі двох культур (украйнсько-англійський словник метафоричних словосполучень ЗМІ: 2000-2015 рр.). Національна академія Національної гвардії України.

Карпіловська, Є. (2017). Роль картотеки “портретів слів” в укладанні словників нового покоління. Studia z Filologii Polskiej i Słowiańskiej, 52, 93-109. https://doi.org/10.11649 /sfps.2017.005

Карпова, О. (2000). Новые тенденции в современной лексикографии. Лексика и лексикография, 2000(11), 63-72.

Клушина, Н. (2019). Современные направления стилистических исследований. In Е. Л. Вартанова (Ed.), Настоящее и будущее стилистики (pp. 300-305). Флинта.

Крехно, Т. (2012). Мотивація запозичень та особливості функціонування полонізмів у новітній українській мові (на матеріалі сучасного україномовного телевізійного простору). Вісник Житомирського державного університету імені Івана Франка, 2012(61), 190-193.

Нелюба, А., \& Нелюба, С. (2007). Лексико-словотворчі інновачії (2004-2006). Майдан.

Пурицкая, Е., \& Панков, Д. (2018). Нормативно-стилистическая характеристика лексики современного русского языка: Возможности описания в словарной базе данных. Вопросы лексикографии, 2018(13), 23-43. https://doi.org/10.17223/22274200/13/2

Сизонов, Д. (2012). Медична термінологія в українських ЗМІ: Словник. “Київський університет".

Степаненко, М. (2017). Політичне сьогодення української мови: Актуальний перифрастикон. Видавець Іванченко І. С.

Стишов, О. (2005). Украӥнська лексика кіния ХХ століття: На матеріалі засобів масової інформації: Монографія. Пугач. 
Тараненко, О. (2000). Новий словник української мови: Концепція і принципи укладання словника. Національна академія наук України.

Чемеркін, С. (2009). Украӥнська мова в Інтернеті: Позамовні та внутрішньоструктурні процеси. Національна академія наук України.

Шевченко, Л., Дергач, Д., \& Сизонов, Д. (2014). Медіалінгвістика: Словник термінів і понять. ВПЦ “Київський університет”.

Шевченко, Л., \& Сизонов, Д. (2017-2019). Нові слова та фразеологізми в українських медіа: Словник (Vols. 1-3). ВПЦ “Київський університет”.

Шевченко, Л., \& Сизонов, Д. (2017). Принципи лексикографічної репрезентації нових слів та фразеологізмів у мас-медіа. Актуальні проблеми української лінгвістики: Теорія і практика, 2017(34), 76-85. https://doi.org/10.17721/APULTP.2017.34.76-85

Шестакова, Л. (2015). О принципах описания иноязычных вкраплений в авторских словарях разных типов. Вопросы лексикографии, 2015(2(8)), 5-26. https://doi.org/10.17223/22274200/8/1

Широков, В. (2004). Феноменологія лексикографічних систем. Наукова думка.

\section{Bibliography (transliteration)}

Adamska-Sałaciak, A. (2019). Lexicography and theory: Clearing the ground. International Journal of Lexicography, 32(1), 1-19. https://doi.org/10.1093/ijl/ecy017

Apresian, I. (1995). Izbrannye trudy: Vol 2. Integral'noe opisanie iazyka i sistemnaia leksikografia. IAazyki russkoĭ kul'tury.

Bańko, M. (2003). Stan i perspektywy współczesnej polskiej leksykografii jednojęzycznej. In S. Gajda (Ed.), Językoznawstwo w Polsce: Stan i perspektywy (pp. 127-142). Polska Akademia Nauk; Uniwersytet Opolski.

Bol'shakov, I., \& Gel'bukh, A. (2011). Bol'shoŭ èlektronny̌̆ slovar' kak politematicheskiı̌ spravochnik i formirovatel' zaprosov k internetu. In A. E. Kibrik et al. (Eds.), Dialog 2011 (pp. 124-134). Izd-vo RGGU.

Chemerkin, S. (2009). Ukraïns'ka mova v Interneti: Pozamovni ta vnutrishn'ostrukturni protsesy. Natsional'na akademiia nauk Ukraïny.

Derhach, D. (2009). Slovnyk onimiv ukraïns'kykh mas-media. "Kyïvs'kyı̆ universytet”.

Dobrosklonskaia, T. (2005). Voprosy izucheniia mediatekstov: Opyt issledovaniia sovremenno angliı̌skoŭ mediarechi. URSS.

Dubichyns'kyı̆, V. (2004). Ukraïns'ka leksykohrafiia: Istoriia, suchasnist' ta komp'iuterni tekhnolohii. NTU "KhPI".

Dubichyns'kyı̆, V. (2015). Suchasna leksykohrafiia XXI st. KhTU.

Dyka, L. (2010). Do problemy pol's'kykh zapozychen' v ukraïns'kykh hovirkakh. In J. Rieger (Ed.), Studia nad polszczyzną kresowa (Vol. 12, pp. 251-258). Wydawnictwo Naukowe Semper. 
Gaĭda, S. (2015). Aktual'nye zadachi stilistiki. Aktual'nye problemy stilistiki, 2015(1), 11-22.

Il'chenko, O. (2012). Verbalizovane "oblychchia” suchasnoho suspil'stva: Slovnyk metaforychnykh slovospoluchen' ukraïns'koï presy (2000-2010). [n.p.].

Il'chenko, O., \& Prystupa, T. (2016). Verbalizovane "oblychchia” suchasnoho suspil'stva v dialozi dvokh kul'tur (ukraïns'ko-anhliǔs'kyi slovnyk metaforychnykh slovospoluchen' ZMI: 2000-2015 rr.). Natsional'na akademiia Natsional'noï hvardiï Ukraïny.

Ivantsova, E. (2013). Leksikograficheskoe predstavlenie rechi individa: Tip slovaria i ego realizatsiia v slovarnoĭ praktike. Voprosy leksikografii, 2013(2(4)), 6-18.

Kafel, M. (1969). Prasoznawstwo. Państwowe Wydawnictwo Naukowe.

Karpilovs'ka, I. (2017). Rol' kartoteky “portretiv sliv" v ukladanni slovnykiv novoho pokolinnia. Studia z Filologii Polskiej i Słowiańskiej, 52, 93-109. https://doi.org/10.11649/sfps.2017.005

Karpova, O. (2000). Novye tendentsii v sovremennoŭ leksikografii. Leksika i leksikografiia, 2000(11), 63-72.

Kirkness, A. (2004). Lexicography. In A. Davies \& C. Elder (Eds.), The handbook of applied linguistics (pp. 54-81). Blackwell. https://doi.org/10.1002/9780470757000.ch2

Klushina, N. (2019). Sovremennye napravleniia stilisticheskikh issledovaniǔ. In E. L. Vartanova (Ed.), Nastoiashchee i budushchee stilistiki (pp. 300-305). Flinta.

Krekhno, T. (2012). Motyvatsiia zapozychen' ta osoblyvosti funktsionuvannia polonizmiv u novitniı̌ ukraïns'kiŭ movi (na materiali suchasnoho ukraïnomovnoho televiziŭnoho prostoru). Visnyk ZHytomyrs'koho derzhavnoho universytetu imeni Ivana Franka, 2012(61), 190-193.

Linde-Usiekniewicz, J. (Red.). (1996). Komputerowy słownik języka polskiego. Wydawnictwo Naukowe PWN.

Maślanka, J. (1976). Encyklopedia wiedzy o prasie. Zakład Narodowy im Ossolińskich.

Neliuba, A., \& Neliuba, S. (2007). Leksyko-slovotvorchi innovatsiï (2004-2006). Maĭdan.

Phillipson, R. (1992). Linguistic imperialism. Oxford University Press.

Pisarek, W. (Ed.). (2006). Słownik terminologii medialnej. Towarzystwo Autorów i Wydawców Prac Naukowych "Universitas”.

Puritskaia, E., \& Pankov, D. (2018). Normativno-stilisticheskaia kharakteristika leksiki sovremennogo russkogo iazyka: Vozmozhnosti opisaniia v slovarnoĭ baze dannykh. Voprosy leksikografii, 2018(13), 23-43. https://doi.org/10.17223/22274200/13/2

Shestakova, L. (2015). O printsipakh opisaniia inoiazychnykh vkrapleniŭ v avtorskikh slovariakh raznykh tipov. Voprosy leksikografii, 2015(2(8)), 5-26. https://doi.org/10.17223/22274200/8/1

Shevchenko, L., Derhach, D., \& Syzonov, D. (2014). Medialinhvistyka: Slovnyk terminiv i poniat'. VPTS “Kyïvs'kyı̆ universytet”.

Shevchenko, L., \& Syzonov, D. (2017). Pryntsypy leksykohrafichnoï reprezentatsiï novykh sliv ta frazeolohizmiv u mas-media. Aktual'ni problemy ukraïns'koï linhvistyky: Teoriia i praktyka, 2017(34), 76-85. https://doi.org/10.17721/APULTP.2017.34.76-85

Shevchenko, L., \& Syzonov, D. (2017-2019). Novi slova ta frazeolohizmy v ukraïns'kykh media: Slovnyk (Vols. 1-3). VPTS “Kyïvs'kyı̆ universytet”. 
Shyrokov, V. (2004). Fenomenolohiia leksykohrafichnykh system. Naukova dumka.

Stepanenko, M. (2017). Politychne s'ohodennia ukraïns'koï movy: Aktual'nyı̆ peryfrastykon. Vydavets' Ivanchenko I. S.

Styshov, O. (2005). Ukraïns'ka leksyka kintsia XX stolittia: Na materiali zasobiv masovoï informatsii: Monohrafia. Puhach.

Svensén, B. (1993). Practical lexicography: Principles and methods of dictionary-making. Oxford University Press.

Syzonov, D. (2012). Medychna terminolohiia v ukraïns'kykh ZMI: Slovnyk. "Kyïvs'kyı̆ universytet".

Syzonov, D. (2018). Media phraseology and the dynamics of the Ukrainian language: The psycholinguistic and stylistic paradoxes. Psycholinguistics, 24(2), 277-292. https://doi.org/10.31470/2309 -1797-2018-24-2-277-291

Taranenko, O. (2000). Novyı̆ slovnyk ukraïns'koï movy: Kontseptsiia i pryntsypy ukladannia slovnyka. Natsional'na akademiia nauk Ukraïny.

Tymoshuk, R., Sosnowski, W., Jaskot, M., \& Ganoshenko, Y. (2018). Leksykon aktywnej frazeologii polskiej i ukraińskiej. KJV Digital Sp. z o.o.

Williams, G. (2016). In praise of lexicography, and lexicographers. In T. Margalitadze \& G. Meladze (Eds.), Proceedings of the XVII EURALEX International Congress (pp. 77-88). Ivane Javakhishvili Tbilisi State University.

Żmigrodzki, P. (Ed.). (2007). Wielki słownik języka polskiego PAN. Instytut Języka Polskiego PAN. http://www.wsjp.pl

\section{The State and Prospects of Discursive- Stylistic Lexicography: An Overview}

\section{Summary}

This article presents a general analysis of traditional and new lexicography. In doing so, it argues for the relevance of discursive-stylistic theoretical approaches and practices in compiling innovative dictionaries. Using the example of Ukrainian and Polish media dictionaries, the authors describe the evolutionary process of transition from print to electronic (computer) dictionaries, and from descriptive to analytical ones. A survey they conducted among students of the Taras Shevchenko National University of Kyiv confirms this process: $84 \%$ of the respondents preferred using new dictionaries based on computer 
technologies. The authors note that the trends observed in Polish and Ukrainian media lexicography are logical in the context of the development of world lexicography. In order to confirm this, they provide an overview of American, German and British media dictionaries. They also describe new Ukrainian dictionaries of the discursive type (e.g. Medialinhvistyka: Slovnyk terminiv i poniat' [Media Linguistics: A Dictionary of Terms and Concepts] by Larysa Shevchenko, Dmytro Derhach and Dmytro Syzonov, 2014) and the frequency type (e.g. Novi slova ta frazeolohizmy v ukraïns'kykh media: Slovnyk [A Dictionary of New Words and Phraseologisms in the Ukrainian Mass Media] by Larysa Shevchenko and Dmytro Syzonov, 2017). The dictionaries are discussed in the context of the development of Ukrainian lexicography and its interrelation with current European, particularly Polish, lexicographic tendencies. The authors plan to continue developing multimedia dictionaries, focusing in particular on collecting media material and its computer processing. The aim of this work is to expand and further organise a dataset for new dictionaries of the twenty-first century, guided by the discursive-stylistic theoretical approach.

\section{Stan i perspektywy leksykografii dyskursywno- -stylistycznej: przegląd problemu}

\section{Streszczenie}

Artykuł przedstawia ogólną analizę leksykografii tradycyjnej i nowej, uzasadniając przy tym istotność dyskursywno-stylistycznych podejść i praktyk teoretycznych w tworzeniu innowacyjnych słowników. Na przykładzie ukraińskich i polskich słowników medialnych opisuje ewolucyjny proces przejścia od słowników drukowanych do elektronicznych (komputerowych) i od słowników opisowych do analitycznych. Ankieta przeprowadzona przez autorów wśród studentów Kijowskiego Uniwersytetu Narodowego im. Tarasa Szewczenki potwierdza zachodzenie tego procesu: $84 \%$ respondentów woli korzystać z nowoczesnych słowników opartych na technologii komputerowej. Autorzy zauważają, że trendy obserwowane w polskiej i ukraińskiej leksykografii medialnej są logiczne w kontekście rozwoju leksykografii światowej, co potwier- 
dza przegląd słowników z USA, Niemiec i Wielkiej Brytanii. Opisane zostały także ukraińskie neosłowniki - typu dyskursywnego (np. Медіалінгвістика: Словник термінів і понять [Media-lingwistyka: Słownik terminów i pojęć] Łarysy Szewczenko, Dmytra Derhacza i Dmytra Syzonowa, 2014) oraz frekwencyjnego (np. Нові слова та фразеологізми в украӥнських медіа: Словник [Nowe słowa i idiomy w ukraińskich mediach: Słownik] Łarysy Szewczenko i Dmytra Syzonowa, 2017). Słowniki te omówiono w kontekście rozwoju ukraińskiej leksykografii i jej relacji ze współczesnymi europejskimi, a szczególnie polskimi, trendami leksykograficznymi. Autorzy planują dalsze prace nad nowoczesnymi słownikami multimedialnymi, w szczególności gromadzenie materiału medialnego i jego przetwarzanie komputerowe. Celem tej pracy naukowej jest dalsza rozbudowa elektronicznej kartoteki, która posłuży za podstawę nowych, dyskursywno-stylistycznych słowników XXI wieku.

Keywords: media lexicography; discursive-stylistic lexicography; lexicographic innovations; media linguistics; language dynamics; the concept of the new dictionary

Słowa kluczowe: leksykografia medialna; leksykografia dyskursywno-stylistyczna; innowacje leksykograficzne; lingwistyka medialna; dynamika językowa; koncepcja nowego słownika

(1) Larysa Shevchenko, Taras Shevchenko National University of Kyiv, Kyiv, Ukraine ORCID: https://orcid.org/0000-0001-6290-2307

Correspondence: shevchenko.knu@gmail.com

(2) Dmytro Syzonov, Taras Shevchenko National University of Kyiv, Kyiv, Ukraine

ORCID: http://orcid.org/0000-0003-1162-2182

Correspondence: dm_sizonov@ukr.net

Authors' contribution: Survey of literature and defining the general line of discussion: the first author (Larysa Shevchenko); outlining the analysis, methodology and state of the art: the second author (Dmytro Syzonov); analysis, drawing conclusions and drafting the manuscript: both authors.

The preparation of this article was self-financed by the authors.

Competing interests: The authors have declared that they have no competing interests. 